\title{
Comparison of $\beta$-Hydroxylase Enzyme 11 Serum in Obese, Overweight, and Normoweight Young Men
}

\author{
Jenny Novina Sitepu, Mutiara Indah Sari , Gino Tann
}

Faculty of Medicine, HKBP Nommensen Medan University, Medan

\begin{abstract}
Background: Previous studies showed that cardiovascular risk factor was increased in obese and overweight subjects. Obesity and cardiovascular risk factor are associated with hypothalamicpituitary-adrenal (HPA) axis hyperactivity that causes hypercortisolism, cortisol level is associated with cardiovascular risk factor on obesity. $11 \beta$-hydroxylase is an enzyme that involved in cortisol synthesis. The aim of this study was to investigate $11 \beta$-Hydroxylase concentration in obesity, overweight, and normal weight young men.

Subjects and Method: This was analytic-observational study using cross-sectional design. The study was conducted at HKBP Nommensen University, Medan. The study subjects included by 76 young men aged 18-28 years old, consisting of 25 obese subjects, 25 overweight, and 25 normoweight. The concentration of $11 \beta$-Hydroxylase was evaluated in blood sample after 10 hours fasting. The data was analyzed bivariately.

Results: Mean of $11 \beta$-Hydroxylase concentration was $52.76 \pm 44.27$ in obese subjects, $70.16 \pm$ 46.83 in overweight subjects, and $43.42 \pm 27.75$ in normoweight subjects. The $11 \beta$-Hydroxylase concentration in overweight subjects was statistically higher than normoweight subjects $(\mathrm{p}=$ 0.007), but the $11 \beta$-Hydroxylase concentration on obese subjects statistically was not different from normoweight subjects $(\mathrm{p}=0.362)$.

Conclusion: The $11 \beta$-Hydroxylase concentration on overweight subject is higher than normoweight subject. There is no difference of $11 \beta$-Hydroxylase concentration on obese and normoweight subject. Mitochondrial stress and mitochondrial failure mechanism on overweight and obesity merit further investigation.
\end{abstract}

Keywords: $11 \beta$-Hydroxylase, cortisol, obesity, overweight

\section{Correspondence:}

Jenny Novina Sitepu. Faculty of Medicine, HKBP Nommensen Medan University, Medan.

\section{BACKGROUND}

Obesity is a condition with excessive fat accumulation in adipose tissue (McPhee et al., 2011). Obesity is one of the health issues of concern to the World Health Organization (World Health Organization/ WHO) (World Health Organization, 2013). According to WHO data, the prevalence of obesity in the world continues to increase (World Health Organization, 2011; World Health Organization, 2013), including in Indonesia (Riskesdas, 2013).

Increased prevalence of excess weight, whether overweight or obesity, is one of the factors that led to an increase in the death rate from non-communicable diseases (World Health Organization, 2011). Obesity is a risk factor for many diseases such as cardiovascular disease and diabetes mellitus type 2 (Obregon, 2010; Tirosh et al., 2011; Schmidt et al., 2013; Juonala et al., 2011), hypercholesterolemia (Ramzan et al., 2011; Rizk and Yousef, 2012; Thakur and Bisht, 2010), and malignant disease (Obregon, 2010).

Obesity and risk of cardiovascular disease is closely related to hyperactivity axis hypothalamic-pituitary-adrenal which caus- 
Indonesian Journal of Medicine (2016), 1(1): 71-75 https://doi.org/10.26911/theijmed.2016.01.01.09

es Hypercortisolism (Anagnostis et al, 2009). A study in the United States (Russell et al., 2009) and Italy (Prodam et al., 2013) showed that cortisol levels associated with cardiovascular risk factors in obesity.

Glucocorticoid hormone cortisol is dominant in humans. This hormone is produced by the adrenal cortex fasciculate zone with the help of the enzyme $11 \beta$-hydroxylase (Barrett et al., 2010). This enzyme is encoded by the genes cytochrome P450, family 11, subfamily $\mathrm{B}$, polypeptide 1 (P45 oc11) or better known as CYP11B1 gene. This enzyme present in the cell membrane of the mitochondria of the adrenal cortex (Miller and Auchus, 2011).This study aims to compare the levels of $11 \beta$-hydroxylase enzyme in male young adults obese, overweight and normal.

\section{SUBJECTS AND METHOD \\ Design and Research Samples}

This research is an analytic study with cross sectional design. Sampling was carried out research at the University of HKBP Nommensen Medan. Intake and blood tests carried out in the Clinical Laboratory Spectrum International Medan.

The samples used in this study were 75 people, divided into three groups, obese, overweight and normal groups. Obese group were male obese (BMI $\geq 25 \mathrm{~kg} / \mathrm{m} 2$ and waist circumference $>90 \mathrm{~cm}$ ), a group of men are overweight (BMI 23 to $24.9 \mathrm{~kg} /$ $\mathrm{m} 2$ and waist circumference $80-90 \mathrm{~cm}$ ), and the group normal is male (BMI 18.5 to $22.9 \mathrm{~kg} / \mathrm{m} 2$ and waist circumference $<80$ $\mathrm{cm})$.Sampling was done by purposive sampling technique. The exclusion criteria were subjects who had a history of hypertension, suffering from Cushing's syndrome (based on history and clinical symptoms).

This study has received permission from the Health Research Ethics Commit- tee Faculty of Medicine, University of North Sumatra and every research subject has given consent after an explanation (informed consent).

\section{Measurement of Body Mass Index and Waist Circumference}

The body mass index is calculated by dividing body weight $(\mathrm{kg})$ by height squared (m2) and recorded 1 decimal places. Weight measurement is done using a digital scale brand Kris. Samples are asked only to use thin clothes (shirt and shorts). Height measurement performed by the meter stature breath (inspiration) long. Waist circumference was measured at the time the subject exhaling (expiratory). Measurement is performed three times and the average value of three measurements was reported as waist circumference in centimeters unit.

\section{Examination of Blood Samples}

Blood samples were taken in the morning (08:00 to 09:00) after a sample of fasting for 10-12 hours. $3 \mathrm{ml}$ of blood is taken in the cubital vein, and then inserted into the tube without ethylene diaminetetraacetic acid (EDTA). Blood serum is separated and stored in a refrigerator at a temperature of $20^{\circ} \mathrm{C}$. This serum is stable up to 4 months. The level of serum 11- $\beta$ hydroxylase performed by quantitative sandwich enzyme immunoassay technique. Levels of 11- $\beta$ hydroxylase samples was determined using a standard curve created by using a program Curve Expert 1.3.

\section{Data analysis}

Data analysis was done using computer software. The results are reported in the average (mean) \pm SD. The test results revealed statistically significant when the $p$ $<0.05$. Any data distribution is determined first by the Kolmogorov-Smirnov normality test. The data were not normally distributed, the transformation first. do not paired $\mathrm{T}$ test with 95\% confidence level ( $\alpha=0.05)$ is 
used to see a comparison of the average levels of the enzyme $11 \beta$-hydroxylase in obese and overweight groups against the normal group.

\section{RESULTS \\ General Characteristics of Samples}

Table 1. Overview of body mass index and waist circumference research subjects

\begin{tabular}{lccccc}
\hline Variables & n & Min. & Max. & Mean & SD \\
\hline BMI (kg/m $\mathbf{m}^{2}$ ) & 75 & 18.6 & 38.2 & 25.20 & 5.11 \\
$\quad$ - Obesitas & 25 & 26.4 & 38.2 & 31.24 & 3.60 \\
$\quad$ - Overweight & 25 & 23.0 & 24.9 & 24.29 & 0.67 \\
- Normal & 25 & 18.6 & 22 & 20.07 & 1.05 \\
& & & & & \\
Waist Size (cm) & 75 & 65 & 117 & 87.97 & 13.73 \\
$\quad$ - Obesitas & 25 & 94 & 117 & 104.24 & 7.52 \\
- Overweight & 25 & 80 & 90 & 85.54 & 4.09 \\
- Normal & 25 & 65 & 80 & 73.74 & 3.62 \\
& & & & & \\
\hline
\end{tabular}

Comparative Levels of $11 \beta$-hydroxylase in the Third Group of Samples. The average levels of $11 \beta$-hydroxylase in the group of obese and overweight was higher than normal. The average levels of $11 \beta$ hydroxylase is highest in the overweight group. $11 \beta$-hydroxylase levels in the overweight group was significantly higher than normal $(p=0.013)$ (Table 2).

Table 2. Levels of $11 \beta$-hydroxylase on obesity, overweight and normal

\begin{tabular}{lccc}
\hline \multicolumn{1}{c}{ Subject } & n & Mean \pm SD & p \\
\hline Obese & 25 & $52.76 \pm 44.27$ & 0.007 \\
Overweight & 25 & $70.16 \pm 46.83$ & 0.362 \\
Normal & 25 & $43.42 \pm 27.75$ & \\
\hline
\end{tabular}

\section{DISCUSSION}

The average value of body mass index in the obese group (31.24 kg / m2) belongs to the category of obesity grade 2 with a risk of severe morbidity (Inoue et al., 2000). The average value of waist circumference obese group (104.24 cm) was also well above normal values (Zimmet and Alberti (2006) in
Samples were aged 18-28 years, with an average of 21 years. Samples majority (66. $7 \%)$ is Batak Toba, $14.7 \%$ are ethnic Nias, 12\% Batak Karo, and Simalungun 6.7\%. Picture of body mass index and waist circumference subjects of research can be seen in Table 1. 
Indonesian Journal of Medicine (2016), 1(1): 71-75 https://doi.org/10.26911/theijmed.2016.01.01.09

the normal group. The average levels of 11 $\beta$-hydroxylase is highest in the overweight group. Bureik et al. in Kaminski \& Rogawski (2011) states that $11 \beta$-hydroxylase is a mitochondrial enzyme that is located in the zone of the adrenal cortex fasikulata. Prasad et al. (2014) mention oxidative stress in mitochondria can occur as a result of the production of Reactive Oxygen Species (ROS) produced during the process of steroidogenesis. This will lead to oxidative stress and mitochondrial disorders in turn will affect steroidogenesis. This may explain why the average level of $11 \beta$-hydroxylase is highest in the group of overweight and obese group the average level of $11 \beta$ hydroxylase obtained close to the normal group. Previous research also showed that cortisol levels in basal conditions were not elevated in the obese group (Pasqualli et al in Kargi and Iacobellis, 2014).

In conclusion, the levels of $11 \beta$ hydroxylase in the overweight group was statistically higher than the normal group, but the levels of $11 \beta$-hydroxylase obese group did not differ significantly with the normal group. The average levels of $11 \beta$ hydroxylase enzyme present in overweight group. The mechanism of mitochondrial stress and mitochondrial failure that occurs in overweight and obese need to be investigated further to explain why the $11 \beta$ hydroxylase levels were higher in the obese group than the overweight group.

\section{REFERENCE}

Anagnostis P, Athyros VG, Tziomalos KA, Karagiannis, Mikhailids DP (2009). The pathogenetic role of cortisol in the metabolic syndrome: a hypothesis. J. Clin Endocrinol Metab 94 (8): 2692-2701.
Andrabi SMS, Bhat MH, Andrabi SRS, Kamili MMA, A Imran, Nisar I (2013). Prevalence of metabolic syndrome in 8-18 year old school-going children of srinagar city of kashmir india. Indian Journal of Endocrinology and Metabolism 17: 95-100.

Barret K, Brooks H, Boitano S, Barman S (2010). Ganong's review of medical physiology 23th edition. USA: The Mc Graw Hill Companies: 337-90.

Humayun A, Shah AS, Alam S, Hussein H (2009). Relationship of body mass index and dyslipidemia in different age groups of male and female population of peshawar. J Ayub Med Coll Abbottabad 2009: 21 (2).

Inoue $\mathrm{S}$, Zimmet $\mathrm{P}$, Caterson I, Chunming C, Ikeda Y, Khalid AK, Kim YS, Basset $J$ (2000). The asia-pacific perspective: Redefining obesity and its treatment.WHO/WPR/Iaso/ IOTF [available from: http://www.wpro.who.Int /nutrition/documents/docs/Redefini ngobesity.pdf?ua=1]-accessed 9 April 2014.

Juonala M, Magnussen CG, Berenson GS, Venn A, Burns TL, Sabin MA, Raitakari OT (2011). Childhood adiposity, adult adiposity, and cardiovascular riskfactors. N Engl J Med 365: 18761885 .

Kaminski RM, Rogawski MA (2011). $11 \beta$ hydroxylase inhibitors as protect againts seizures in mice by increasing endogenous neuroactive steroid synthesis. Neuropharmacology 6(1): 133137.

Kargi AY, Iacobellis G (2014). Adipose tissue and adrenal glands: novel pathophysiological mechanism and clinical applications. International Journal of Endocrinology 226(1): 1-11. 
McPhee SJ, Papadakis MA, Rabow MW. (2011). Current medical diagnosis and treatment, 15th edition. USA: McGraw Hill Companies: 1202-4.

Miller WL, Auchus RJ (2011). The molecular biology, biochemistry, and physiology of human steroidogenesis and its disorders. Endocrine reviews 32: 81-151.

Obregon MJ (2010). Maternal obesity results in offspring prone to metabolic syndrome. Journal of Endocrinology 151 (8): 3475-3476.

Prasad R, Kowalczyk JC, Meimaridou E, Storr HL, Metherell LA (2014). Oxidative stress and adrenocortical insufficiency. Journal of Endocrinology 221: R63-R73.

Prodam F, Ricotti R, Agarla V, Parlamento S, G Genoni, Balossini C, Bellone S (2013). High-end normal adrenocorticotropic hormone and cortisol levels are associated with specific cardiovascular risk factors in pediatric obesity: a cross-sectional study. BMC Medicine 11:44.

Purnell JQ, Brandon DD, Isabelle LM, Loriaux DL, MH Samuels (2004). Association of a 24-hour cortisol production rates, cortisol-binding globulin, and plasma-free cortisol levels with body composition, leptin levels, abd aging in adult men and women. J. Clin. Endocrinol. Metab 89(1): 281287.

Ramzan M, Ali I, Ramzan F, Ramzan F, Ramzan MH (2011). Waist circumference and lipid profile Among primary school children. JPMI 25(3): 222-226.

Basic Health Research (Riskesdas) (2013). Agency for Health Research and Development Ministry of Health of the Republic of Indonesia Year 2013 Ja- karta: Ministry of Health of the Republic of Indonesia.

Rizk NM, Yousef M (2012). Association of lipid profile and waist circumference as cardiovascular risk factors for overweight and obesity Among school children in qatar. Diabetes, Metabolic Syndrome and Obesity: Targets and Therapy 2012: 5425-432.

Russel M, Bredella M, Tsai P, Miller KK, Klibanski A, Misra M (2009). Relative growth hormone and excess are associated with Increased cardiovascular risk markers in obese adolescents girls. J Clin Endocrinol Metab 94: 2864-2871.

Schmidt M, Johannesdottir SA, Lemeshow SA, Lash TL, Ulrichsen SP, Botker HE, Sorensen HT (2013). Obesity in young men, and individual and combined risks of type 2 diabetes, cardiovascular morbidity and death before 55 years of age: danish 33years follow-up study.

JS Thakur, Bisht S (2010). Comparative study of blood lipid profile of obese and non-obese sedentary college men. VSRD-TNTJ I (1): 26-29

Tirosh A, Shai I, Afek A, Dubnov-Raz G, Ayalon N, Gordon B, Rudich A (2011). Adolescent bmi trajectory and risk of diabetes versus coronary disease. $\mathrm{N}$ Engl J Med 364: 1315-1325.

WHO (2008). Waist Circumference and Waist-Hip Ratio; Report of a WHO Expert Consultation. Geneva: WHO. . (2011). Noncommunicable Diseases. Country Profiles. Geneva: WHO. - (2013). Global Health Statistics 2013 Part III. Global Health Indicators. Geneva: WHO. 